UDC: 801.55:811.111 https://doi.org/10.22190/JTESAP2104643E

Review research paper

\title{
INNOVATIVE TEACHING METHODS IN A CULTURE INTEGRATED ENGLISH LANGUAGE COURSE
}

\author{
Elizaveta Egorova \\ Saint Petersburg State University, Russia
}

\begin{abstract}
The relevance of the study is dictated by the demand of the state for training competitive specialists who are ready to maintain an intercultural dialogue in their professional field. The main goal of modern language education is the development of innovative integrated courses that enable students to enrich their subject knowledge and to master the ability to use this knowledge at the international level. This article considers Content and Language Integrated Learning (CLIL) and English for Specific Purposes $(E S P)$ to be promising ways of implementing the integrative approach into the education system. Many methodologists and linguists have proven the effectiveness of interconnected teaching foreign languages and cultures, resulting in the selection of a culture-based course designed in English as an object of the research. With a view to developing students' professional foreign language competence and enriching subject knowledge, the educational process includes using digital tools provided by museums around the world (the State Hermitage Museum, the Louvre Museum, the British Museum, the Rijksmuseum, the Metropolitan Museum of Art, the Uffizi Gallery, The Vatican Museums), as well as the tasks based on these authentic resources. The study reveals that digital archives, online art collections, 'Virtual Visit', audio and video resources are valuable sources of authentic materials that can be used in the process of professionally oriented English teaching.
\end{abstract}

Key words: integration, culture, English for Specific Purposes, Content and Language Integrated Learning, professional foreign language competence, learning effectiveness, digital tools

\section{INTRODUCTION}

The Russian education system responds vividly to the development trends that characterize modern world society. The process of globalization, the increase in direct contacts in the field of professional communication, the expansion of opportunities for academic mobility and career growth in the international market (including the use of various digital tools and communication means) change the definition of the main goals and the objectives of the higher education.

The Russian system of legal regulation in the field of education emphasizes that university graduates should have "the ability to communicate in oral and written forms in Russian and foreign languages in order to solve problems of interpersonal and intercultural

Submitted March $4^{\text {th }}, 2021$, accepted for publication May $5^{\text {th }}, 2021$

Corresponding author: Elizaveta Egorova. Saint Petersburg State University, Russia

E-mail: egorova13elizaveta@gmail.com 
interaction" (FSES, 2015, p. 7). This idea is enshrined in the State educational standards for various subject areas.

Modern global trends are also reflected in a unique Russian project - 'Atlas of Emerging Jobs', developed by the Moscow School of Management SKOLKOVO and the Agency for Strategic Initiatives. A valuable feature of this project is not only a list of those jobs that will appear in the near future and will be relevant for the world economy, but also a list of cross-professional skills that will determine competitive and promising specialists. Among such universal skills we should note cross-industry communication skills, systems thinking, ability to manage projects and processes, multilingual and multicultural abilities (Atlas, 2020, p. 23-24). The last two abilities are of special importance in the modern system of language education, which is reflected in the Common European Framework of Reference for Languages (CEFR).

Thus, the main task of researchers, methodologists, teachers and pedagogical designers is to develop innovative learning models. The main goal of such models is to train competitive and prospective professionals who have comprehensive knowledge in their subject area and the ability to share their experience with experts from other countries. The ability to maintain intercultural dialogue and achieve the desired results is one of the key factors that employers pay special attention to. That is why professionally oriented teaching foreign languages is a new direction in the development of the modern education system.

In an effort to rethink the actual functioning of the education system in accordance with the development trends of modern society and the demands of the state, many researchers pay attention to the possibility of interdisciplinary 'integration'. "The process of unification, synthesis or cooperation that occurs or is carried out in education regarding the objects of different nature" (Skvortsov, 2014, p. 42) can significantly increase the effectiveness of training future specialists, which is a viable response to the challenges of modern society.

\section{LITERATURE REVIEW}

After analyzing the works of modern researchers in the field of integration processes (Skvortsov V. N., Brazhnik E. I., Solomin V. P., etc.), the following characteristic prerequisites for the emergence of interdisciplinary courses were identified:

- the presence of two or more disciplines that were not previously considered as possible components of one integrated course;

- the presence of obvious conditions for the unification of these disciplines or their constituent parts;

- the possibility of creating a holistic, logical and systemic integrated course;

- the possibility of including the resulting integrated course in the educational process;

- the prospect of further development of the course to increase the effectiveness of training.

Interdisciplinary courses, developed within the framework of an integrative approach and meeting the demands of modern society, should involve a combination of three components, which Brazhnik E. I. identifies in her work:

- cultural (introduction of the cultural heritage of the native country and the country of the language being taught to students);

- linguistic (mastering the level of foreign language proficiency);

- communicative (formation of students' communicative skills through participation in different conferences, seminars, debates, competitions, etc.) (Brazhnik, 2005, p. 178). 
The most effective and popular ways of implementing the integrative approach into the education system are methodological models of Content and Language Integrated Learning (CLIL) and English for Specific Purposes (ESP), where a foreign language acts as "a means of forming professional knowledge and skills" (Almazova, Baranova, Khalyapina, 2017, p. 120), as well as "a means of systematic professional knowledge enrichment" (Matukhin, 2011, p. 124). For several decades, these approaches have been an integral part of technical and humanitarian programs both in Europe and in Russia. It should be noted that these models are applicable not only to the higher education system; integration trends are characteristic for different levels of education, including preschool, primary and secondary education.

In recent decades, many European and Russian researchers have been devoting their works to clarifying the definition of CLIL and ESP models, highlighting their key characteristics and confirming the effectiveness of their implementation in the educational process. One of the fundamental works in the area of ESP learning is "Developments in English for Specific Purposes: A multi-disciplinary approach" (1998) by Tony Dudley-Evans and Maggie Jo St John. The British linguists identify the following absolute and variable characteristics of ESP:

- absolute characteristics:

- meeting the specific needs of students;

- using of the methodology and activities characteristic of the discipline being taught;

- focusing on language (grammatical and lexical units, register), skills and discourse appropriate to the discipline being taught.

- variable characteristics:

- direct relationship with specific disciplines;

- using a different methodology from that of general English, if required by a specific educational situation;

- intended mainly for adult learners who are at the stage of higher or vocational education;

- intended mainly for intermediate and advanced learners (Dudley-Evans, 1998, p. 4-5).

Based on the above characteristics, the definition of the ESP model is formulated as follows: ESP is an approach characterized by the development of specialized language courses, the purpose of which is to use a foreign language to meet professionally oriented communicative needs of the students. Thus, ESP is distinguished by its personalityoriented nature, it provides an opportunity to master language skills and forms the ability to use subject knowledge in the context of intercultural communication.

As for the CLIL model, in this article we will adhere to the following definition: CLIL is an approach characterized by its dual nature, which implies "the simultaneous mastery of knowledge in the subject area and the ability to use this knowledge in a foreign language" (Tarnaeva, Baeva, 2019, p. 283). Within the framework of this approach, a foreign language becomes a kind of mediator in studying subject knowledge, while subject knowledge is a resource for mastering a foreign language. Integrated courses created according to the CLIL model are a balanced combination of both subject and linguistic components, and none of them largely prevails over the other.

One of the fundamental characteristics of the CLIL methodology is the concept of "four Cs" (the 4Cs Framework). It implies the interconnected use of such components as 
content, communication, cognition and culture within the framework of integrated courses. In other words, the CLIL model assumes the presence of subject knowledge, the ability to use linguistic means, the development of cognitive skills and the improvement of intercultural awareness (Coyle, 2006, p. 9). Moreover, the content component is system-forming; "it defines the subject of learning, goals, objectives and themes, i.e. a set of theoretical knowledge and skills that allow to express correct professional opinions and statements within the studied range of problems" (Almazova, Baranova, Khalyapina, 2017, p. 121)

At present, there are many varieties of ESP (English for physicians, for pilots, for lawyers, for engineers, for chemists, for managers, for financiers, etc.); there are also CLIL courses in different fields. However, it should be noted that the discipline 'Foreign language' and the disciplines of the humanities cycle can be integrated into a single course in the most natural and effective way. For many decades, the idea of a close relationship between language and culture has not ceased to interest linguists, philologists, philosophers, anthropologists and specialists in other humanitarian fields (Armstrong N., Hall E., Trager G., Samovar L., Porter R., McDaniel E., Elizarova G.V., Kabakchi V.V., Ter-Minasova S.G., etc.). That is why the interconnected teaching foreign languages and cultures will not lose its relevance and will be widespread in various higher educational institutions.

Today, one of the main goals of teaching foreign languages is teaching students the language of intercultural communication, namely English. Life and learning in the era of 'neoglobalization' give particular importance to the process of intercultural communication, which implies the ability of interlocutors to use the entire linguistic potential of a global language (English) to represent various national cultures on the world stage. In this regard, one cannot fail to note the historically formed prejudice and negative stereotypes of representatives of some nations towards others. Therefore, the mission of overcoming such stereotypes and presenting one's own country and its culture to the outside world, using English in its current role as the world lingua franca becomes extremely important (Kabakchi, Beloglazova, 2017, p. 195).

Teaching foreign languages today is "impossible without cross-disciplinary approach, integration, which today act as the main methodological prerequisites for learning the surrounding reality" (Kostina, 2015, p. 92). In this context, we tested in practice the integrated course 'St Petersburg History and Culture in English', which became a successful addition to the educational process.

The course 'St Petersburg History and Culture in English' allowed students to master their skills in all aspects of the language (phonetics, vocabulary and grammar) and four types of speech activity (listening, reading, speaking and writing), as well as to acquire comprehensive knowledge about St Petersburg culture, determine its place within the framework of Russian and world cultures. Moreover, this course allowed students to understand "what to pay attention to, what to take for granted, in which cases it is possible to reduce differences to a minimum, how to integrate into a new cultural space, tactfully emphasizing their national and cultural identity" (Getmanskaya, 2014, p. 109).

However, this article aims to highlight the features of a culture integrated Englishlanguage course in general and to offer activities that are based on the use of authentic digital tools and that make a great contribution to the formation of professional foreign language competence of students. 


\section{METHOD}

Taking into account the specificity of the research problem, we used theoretical methods that reflect the principle of a systematic approach to the analysis of the phenomena under study: analysis, comparison, synthesis, generalization. The methodological basis of this study includes publications in the field of interdisciplinary integration, the relationship between language and culture, teaching English for Specific Purposes, Content and Language Integrated Learning, using authentic materials and digital tools in the educational process.

\section{DISCUSSION}

Many researchers note that interdisciplinary integration makes a great contribution to professionally oriented learning, and also allows to create "an innovative educational environment with the implementation of results-based mechanisms" (Kurmangulov, 2018 , p. 37). Undoubtedly, this approach improves the students' activity in the learning process, as well as their cognitive and creative potential (Shishmolina, 2020, p. 186).

Authenticity is one of the most important principles of innovative interdisciplinary courses aimed at implementing personality-oriented technologies. Authentic materials, the creation of which did not imply their use for educational purposes, contributes to "improving communicative competence of students" and "creating innovative, creative, collaborative, cooperative learning through facilitation of learning that is capable of generating critical thinking, supporting each other (sharing ideas), problem solving skills, the ability to negotiate (negotiating), provide service orientation, and have cognitive rigidity with a high level of critical thinking" (Ginaya et al, 2019, p. 1086). Meanwhile, authentic materials are not limited to written texts; today's integrated courses make extensive use of various oral texts and activities that are close to real life.

The British educational resource 'Career Paths' could serve as a traditional basis for a culture-based course designed in English. This resource offers such teaching materials as 'Career Paths: Museum Management \& Curatorship', 'Career Paths: Art \& Design', 'Career Paths: Tourism', etc. An integrated culture-based course can also be based on Russian Student's Books such as 'English and World Culture. Lectures and Exercises. A manual on art history' (Getmanskaya A. V.), 'How to Speak about Art in English' (Falkovich M. M., Lebedinskaya E. M., etc.), 'English for art historians' (Alaeva O. V.), etc.

Express Publishing Student's Books are divided into three parts, which correspond to the three levels of language proficiency, according to CEFR - A1, A2 and B1. Each part of these Student's Books includes 15 different topics, which offer tasks aimed at developing four language skills - reading, listening, speaking and writing. Particular attention is paid to increasing the students' vocabulary, since teaching professionally oriented vocabulary is fundamental in any ESP course, in particular in the field of cultural studies. The educational resource 'Career Paths' also includes a Teacher's Guide and a set of 2 Audio CDs for each Student's Book.

Russian Student's Books are designed for a wide range of learners who have an advanced level of English proficiency. Substantive and informative texts on the subject are the defining characteristics of these resources. The main purpose of the Student's Books is to teach professionally oriented vocabulary, develop language skills (in particular, speaking and writing), and provide students with basic information about the world art and culture. 
Various digital tools offered by museums around the world can be an additional authentic resource to both British and Russian Student's Books. It should be noted that a modern museum is an international communicative space that contributes to "the formation of a creative multicultural linguistic personality interested in mutual enrichment and mutual understanding of the world nations and in preserving the values of global culture as a whole" (Getmanskaya, 2019, p. 393).

Leading in the field of modern language education, the communicative approach is also characteristic of a modern museum industry. The concept of 'understanding museology' is becoming more and more popular; it implies a respectful attitude to the opinions of all participants in museum communication (creators, critics, experts, guides, visitors, etc.), "fostering tolerance for foreign cultures, awakening interest and respect for them, overcoming feelings of irritation from redundancy, insufficiency, or dissimilarity of other cultures" (Ter-Minasova, 2000, p. 8).

Consequently, a detailed analysis of existing digital tools and a selection of the best ones is becoming one of the main goals for the designers of modern culture-based courses in English. Such digital tools can be used as an effective authentic material in order to develop the foreign language professional communicative competence of students. They add to the educational process extra opportunities for organizing active and interactive classes, which keeps students motivated and stimulates their creative and research potential.

The analysis of different authentic digital tools revealed that the most valuable ones are located on the museum official websites, their accounts on social networks and various online platforms. Taking into consideration the principle of forming integrated language skills, which dominates the system of modern language education, we will analyze digital tools in accordance with the language skills that they form (listening, speaking, reading, writing).

Many museums around the world provide a variety of audio resources (audio guide tracks, podcasts, recordings of past lectures and conferences, audio descriptions of museum masterpieces, etc.) that can be used in the educational process to improve students' listening skills. Such audio recordings are often accompanied by a brief written description or an image of a museum object, which act as an additional stimulus for oral comprehension.

A rich collection of audio recordings is offered by the British Museum - 'Audio Descriptive Guide', available on the online platform SoundCloud. More than 150 tracks provide detailed, professionally described information about the main milestones in human history and culture, as well as the British Museum masterpieces. These short tracks (2-3 minutes) can be used in class while studying such topics as Ancient Egypt, Ancient Greece, Africa, Asia, Early and Medieval Europe, Sculpture, Portrait, Applied Art, etc. Here is an example of an assignment aimed at improving listening skills, based on the digital tool 'Audio Descriptive Guide':

Task 1. Listen to an audio recording (Track 6) describing the Greek art. Decide whether the following statements are true or false. While listening, take notes to prove your choice with phrases from the audio.

a) The majority of the surviving Parthenon sculptures are displayed in the British Museum and the Louvre Museum in Paris.

b) The ancient Greeks were intensely interested in the human condition, exploring all aspects of the human mind and body.

c) By the end of the 1st century BC Rome governed the former Greek lands.

d) None of the sculptures, tools, ornaments, household items and architectural fragments are connected with religious practices and beliefs about the afterlife. 
Another interesting digital tool for effective teaching listening skills is published on the official website of the State Museum of the Netherlands - Rijksmuseum. The museum staff has developed a unique project "One hundred masterpieces", which enables students to get acquainted with the world-famous masterpieces that are located in the Rijksmuseum. Short audio recordings detail the history of the creation of such paintings as 'The Jewish Bride', 'The Night Watch' and 'Self-portrait' by Rembrandt, 'The Milkmaid' and 'The Little Street' by Vermeer, 'Madonna of Humility' by Fra Angelico, 'Girl in Blue' by Verspronck, 'Selfportrait' by Van Gogh, 'Portrait of Don Ramón Satué' by Francisco de Goya, 'The Battle of Waterloo' by Pieneman and many others. The following is an example of a listening task that can be used in the process of teaching English in the field of cultural studies:

Task 2. Listen to the audio recording and complete the description 'The Night Watch' by Rembrandt. Use only one word for each gap:

Why is The Night Watch so world famous? After all, it's basically just a of $a$ group of civic guardsmen in the 17th century ___. Members of the civic guards defended the city and preserved public order. They are about to set off on a march through the city. However, because the painting is so people in the 19th century have it the title of 'Night Watch'. In other words, appearances are deceiving. Rembrandt often used dark in his paintings. This enabled him to literally put his figures in the so creating a dramatic effect.

Not only the lighting, but the guardsmen's gestures and poses, too, capture our attention. Instead of following the Rembrandt opted for this rather disorderly and portraying the men ranked in line, , suggesting they're about to advance. It's a group in action, and that's precisely what makes this painting so

In addition to audio recordings, a lot of museums around the world publish on their websites various videos dedicated to the main masterpieces of the collection, past and upcoming exhibitions, cultural events, the history of the museum. 'The Elements of Art' on the Louvre Museum website, 'Curator's Corner' on the British Museum YouTube channel, 'Une œuvre, un regard' (season 1 in English) on the Musée d'Orsay YouTube channel could be taken as an example. Professional guides, art historians, curators and art critics act as storytellers in these videos. Various activities can be based on these authentic videos; they allow students to improve their listening skills, as well as to acquire valuable professional knowledge.

Teaching foreign monologue speech is often based on working with printed texts or using an authentic sample of oral monologue utterance. Thus, in the first case, the development of activities can be based on the use of the 'Virtual Visit' digital tool, which is available on the official websites of most museums in the world (the State Hermitage Museum, the State Russian Museum, the Louvre Museum, the British Museum, the Uffizi Gallery, etc.) This digital tool enables to make a real journey around the museum: to demonstrate its halls, to get acquainted with the museum collection, to visit permanent and temporary exhibitions. Moreover, this resource provides essential information about the interiors and the works of art located in the museum. Therefore, such a 'visit' can be used as a means of developing speaking skills (for example, conducting a guided tour, describing a hall or an art object).

The following is an example of a task aimed at improving the monologue speech skills, which is based on the 'Virtual Visit' digital tool published on the official website of the State Hermitage Museum: 
Task 3. Imagine that you are to organize an art exhibition. First, choose a theme for your future exhibition, for example, 'Retrospective of paintings by a famous artist' or 'Presentation of one of the artistic movements'. Second, select the necessary information using the functionality of the 'Virtual Visit' of the State Hermitage Museum websit. Then, decide which works of art will be displayed at your exhibition. Finally, present the results of your mini-project to the group.

Another valuable digital tool that enables to improve students' monologue speech skills is located on the official website of the Louvre Museum. The 'Tales of the Museum' section offers a series of animated video stories that describe various works of art, secrets of their creation, discovery, acquisition, and restoration. The narrator of these videos is the first director of the Louvre Museum -Dominique-Vivant Denon. Activities developed on the basis of this authentic resource could be to watch these videos, and then voice them independently (with the sound of the video turned off):

Task 4. Watch a video about the masterpiece of Greek sculpture - Venus de Milo. While watching the video, take some notes. Then the teacher will mute the video and you will have to voice it. Use your notes and facts that you have memorized. Try to speak fluently to keep up with the plot of the video.

Official websites of different world famous museums can also be used as a means of improving students' dialogue speech skills. For example, students are to explore the website, the history of the museum collection, its permanent and temporary exhibitions, educational and cultural events that are held there. Then, students should discuss this information in class and make a plan to attract visitors to the museum. This task can be performed both in pairs and in groups. The main goal of this discussion is to come to a consensus and form a coherent and logical plan of the museum staff's actions.

Modern digital tools make it possible to find valuable authentic material for improving reading skills - scanning, skimming, reading for detailed comprehension, critical reading. Many museums around the world provide comprehensive information about the museum history, the museum masterpieces, and interesting facts about outstanding artists on the pages of their official websites. For example, the 'Collection \& Louvre Palace' section of the Louvre Museum invites visitors to get acquainted with its collection through the digital project 'Curatorial Departments'. Thus, students can be involved in doing the following task to develop their reading skills for detailed comprehension:

Task 5. Read the passage and find words/phrases, which are synonymous to the words/phrases in the list below. Then make up sentences with them:

In the early nineteenth century, Venice was a favorite destination for artists. Made fashionable, particularly by Lord Byron, the city became the symbol of a disappearing world, and of the magnificent deliquescence so prized by the Romantics. Bonington made the trip in 1826 and painted many views of the city, both in oils and in watercolors. The swiftness of Bonington's brushwork was ideally suited to the changeable character of light on the lagoon.

Synonyms: popular, image, vagueness, rapidity, variable

Many museums are actively involved in research and publication work. Official museum websites often provide digital archives of publications; some museums regularly publish their own magazines. A bright example is the Metropolitan Museum of Art, which has been publishing the Metropolitan Museum Journal for over 50 years. The Journal provides different research and critical works, monographic reviews related to works of art and their cultural context, new information based on the latest researches, 
etc. These articles are particularly effective for improving scanning and skimming skills, they also serve as a rich resource for enriching students' professional vocabulary. However, it should be noted that this digital tool is suitable for learners with an advanced level of English proficiency. The task based on one of the Metropolitan Museum Journal articles is presented below:

Task 6. Briefly read the article 'Two "Etruscan" Vases and Edgar Allan Poe' by Nancy Hirschland Ramage and R. D. Cromey from Metropolitan Museum Journal v. 48 (2013), pp. 169-177. Then make a detailed plan of the article that clearly reflects its main points. The article is available in the section 'MetPublications' on the official website of the museum (use this link to find the article: https://www.metmuseum.org/art/metpublications).

Numerous digital tools can be used to improve students' writing skills within the setting of a culture-based course designed in English. Online art collections located on the websites of world museums are precious digital tools. This resource enables students to examine museum works of art in the smallest detail, as well as to find out additional information about its artist, time and place of creation, material, technique, size, and other descriptions (the main distinctive features, functional purpose, artistic style, events and persons associated with this work of art, symbolic meaning, possible interpretations, etc.). Obviously, in the process of teaching a culture-based course, this digital tool can serve as a high-quality visual accompaniment of the subject material. However, this article covers the value of digital collections only in terms of improving students' language skills, particularly writing. The following is an example of the task that is based on the Uffizi online collection 'Artworks':

Task 7. Write a review for the magazine dedicated to the world culture and art. The theme for your review is your impression of the exhibition you have just visited or the picture you have seen. Use a semi-formal style. The review should consist of an introduction (the main details), a main body (the details requested by the rubric) and a conclusion (a summary of a main body and your positive or negative opinion). Use the digital collection of the Uffizi Gallery to find interesting and quality information. For example, you can analyze Raphael's 'Self portrait', Botticelli's 'Birth of Venus', Michelangelo's 'Holy Family' and many other paintings.

It should not be forgotten that social networking is a new type of communication that occupies a special place in the modern world. It differs from other types of written communication (for example, by e-mail or on the forum). Its characteristic features are the brevity and density of messages, which are short in volume, but meaningful in sense. The use of emotionally colored vocabulary and syntactical expressive means also distinguishes social networking. That is why teaching this type of written communication becomes another goal of any English course.

Let us take up the example of the official museum accounts on the Instagram social network, which is one of the most popular nowadays. This digital tool offers its users many opportunities - to post their photos and videos, to supplement them with descriptions, to make Stories, and to participate in live broadcasts. It is interesting to note that many museums around the world run their Instagram accounts in two languages simultaneously - in the national language (where the museum is located) and in English. This feature enables students to improve their multilingual competence, the importance of which was noted above. An example of a task that is based on the posts published in the account of the Vatican Museum is presented below: 
Task 8. Imagine that you are in charge of running the Instagram account of a famous museum. You need to write a post that grabs the attention of your readers. Take a close look at how colleagues at the Vatican Museum do it. Choose your favorite piece of art and create a similar description based on this example:

(7) Wednesday is \#SistineunSeen! Today we return to the Ceiling where through nine scenes the "bereshit", that is the absolute "beginning" of being is evoked.

: The creation of the sun and the moon is one of the most intense and expressive frescoes in the \#SistineChapel. The figure of God is extraordinarily powerful and imperious: in the frown and severe gaze, in the beautiful virile face and in the peremptory gesture of the hands that give life to the incandescent disk of the sun and the icy disk of the moon.

() Michelangelo incorporates the iconographic tradition of God to be old and with a white beard, but gives him a tempestuous and terrible strength. His face is struck by a beam of light that makes it even more expressive, while the hand pointing towards the solar disk has an extraordinary naturalness.

The use of the abovementioned digital tools when completing different activities makes a significant contribution to improving the professionally oriented foreign language competence of students. A creative and critical approach to solving a given problem, the desire to achieve a practically meaningful result and present their work in front of an audience motivates students in the process of learning a foreign language.

\section{CONCLUSION}

Modern language education is aimed at keeping up with global trends; therefore, it makes extensive use of various digital tools. Culture-based courses in English, taught in higher educational institutions, are no exception. The official websites of museums around the world provide many unique opportunities such as digital archives, online art collections, audio and video resources, 'Virtual Visit', etc. Social media accounts of museums, in particular, Instagram, as well as various online platforms are valuable sources of authentic material that can be used in the process of professionally oriented teaching foreign languages.

The digital tools analyzed in this article make a significant contribution to the formation of professionally oriented foreign language competence of students: they improve all language skills (listening, speaking, reading, writing), and are a rich source of professional vocabulary. Moreover, such authentic resources maintain a keen interest of students in the subject under study, contribute to the development of their creative and research capacity, and prepare them to participate in intercultural interaction at a professional level.

\section{REFERENCES}

Almazova, N.I., Baranova, T.A., Khalyapina, L.P. (2017). Pedagogical approaches and models of integrated teaching of foreign languages and professional disciplines in foreign and Russian linguodidactics. Language and Culture, 39, p. 116-134. DOI: $10.17223 / 19996195 / 39 / 8$

Armstrong, N. (2005). Translation, Linguistics, Culture. A French-English Handbook. Clevedon, Buffalo and Toronto: Multilingual Matters Ltd, 218 p. 
Artworks (the Uffizi Gallery) (2020). Available at: https://www.uffizi.it/en/artworks (accessed 5 February 2021).

Atlas of Emerging Jobs (2020). Available at: https://atlas100.ru/upload/pdf_files/atlas.pdf (accessed 10 February 2021).

Brazhnik, E. I. (2005). Formation and development of integration processes in modern European education. Siberian Pedagogical Journal, 5, p. 166181.

Brazhnik, E. I., Surtayeva, N. N., Surtayeva, Zh. B. (2012). Comparative studies of university education in the contemporary context of integration processes. Man and Education, 3 (32), p. 61-65.

British Museum. Audio Descriptive Guide (2020). Available at: https://soundcloud.com/ britishmuseum/sets/new-audio-descriptive-guide (accessed 15 January 2021).

Coyle, D. (2006). Content and language integrated learning: Motivating learners and teachers, In Scottish Languages Review, 13, p. 1-18.

Curatorial Departments (the Louvre Museum) (2018). Available at: https://www.louvre. fr/en/departements (accessed 10 February 2021).

Dudley-Evans, T., Saint John, M. J. (1998). Developments in English for specific purposes: A multi-disciplinary approach. Cambridge, Cambridge university press, $301 \mathrm{p}$.

Elizarova, G. V. (2009). On the difference between intercultural interaction and communication. Studia Linguistica, 18, p. 229-243.

Federal State Educational Standard of Higher Education (Cultural studies) (2015). Available at: http://fgosvo.ru/uploadfiles/fgosvob/510301.pdf (accessed 10 February 2021).

Getmanskaya, A. V. (2014). On the peculiarities of intercultural communication in the context of the polylogue of cultures. Translation. Language. Culture, p. 108-114.

Getmanskaya, M. K., Getmanskaya, A. V. (2019). Polycultural linguistic personality development in the process of teaching foreign languages. Philology. Theory and Practice, 5, p. 390-394.

Ginaya, G., Somawati, N. P., Aryana, I. N. R., Putra, I. M. A. (2019). Improving Students' Communicative Competence through Inductive Method Using Authentic Materials. In Journal of Language Teaching and Research, 10(5), p. 1080-1088.

Hall, E. T., Trager, G. L. (1953). The Analysis of Culture. Washington, D. C.: American Council of Learned Societies, $62 \mathrm{p}$.

Kabakchi, V. V., Beloglazova, E. V. (2017). Teaching Russian-culture-oriented English: What for and how to. STUDIA LINGUISTICA, 24, p. 195-208.

Kabakchi, V. V., Beloglazova, E. V. (2018). Introduction to interlinguoculturology: tutorial. Moscow, Izdatel'stvo Yurajt, $251 \mathrm{p}$.

Kostina, E. A. (2015). Cross-cultural in philosophical thought as the basis of crosscultural in education. Philosophy of Education, 5 (62), p. 84-101.

Kurmangulov, A. A., Reshetnikova, Ju. S., Bagirov, R. N., Frolova, O. I., Brynza, N. S. (2018). «Factory of Processes» - A New Format of Educational Process Organization at Higher Education Institution. Higher Education in Russia, 5, p. 3741.

Matukhin, D. L. (2011). The Professionally Oriented Teaching Foreign Language Teaching to Students of Non-Linguistic Specialties. Language and Culture, 2 (4), p. 121-129.

Metropolitan Museum Journal V. 48 (2013). Available at: https://www.metmuseum.org/ art/metpublications/The_Metropolitan_Museum_Journal_v_48_2013 (accessed 5 February 2021).

One hundred masterpieces. Rijksmuseum (2021). Available at: https://www. rijksmuseum.nl/en/stories/one-hundred-masterpieces (accessed 10 February 2021). 
Samovar, L. A., Porter, R. E., McDaniel, E. R. (2010). Communication between cultures. Boston, MA: Wadsworth Publishing, 463 p.

Shishmolina, E. P. (2020). Interdisciplinary foreign language teaching as means of selforganization ability building by new generation specialists. Perspectives of Science \& Education, 3 (45), p. 182-194. DOI: 10.32744/pse.2020.3.14

Skvortsov, V. N. (2014). Integration in education and ways of classifying integrated education systems. Bulletin of State University named after A. S. Pushkin, 3, p. 40-52.

Solomin, V. P. (2012). Interdisciplinary integration as a vector for the development of modern pedagogy. UNIVERSUM : Bulletin of Herzen University, 3, p. 3-15.

Tales of the Museum (the Louvre Museum) (2018). Available at: https:// www.louvre.fr/en/tales-of-the-museum (accessed 19 January 2021).

Tarnaeva, L. P., Baeva, G. A. (2019). Content and language integrated learning in the system of linguistic education: pro et contra. Languge and Culture, 45, p. 281-298. DOI: $10.17223 / 19996195 / 45 / 20$

Ter-Minasova, S. G. (2000). Language and intercultural communication, Moscow, Slovo, $624 \mathrm{p}$.

Ter-Minasova, S. G. (2015). Contradictions of International Communication in the Era of Globalization: Obstacles or Driving Forces? In Russian Journal of Linguistics, 19 (4), p. 4348 .

Vatican Museums (2016). Available at: https://www.instagram.com/vaticanmuseums (accessed 7 February 2021).

Virtual Visit (the State Hermitage Museum) (2020). Available at: https://www. hermitagemuseum.org/wps/portal/hermitage/panorama/virtual_visit?lng=en (accessed 20 January 2021). 